\title{
Analysis of the Influence of Gas Distribution on Flora Structure and Oil Displacement Effect During Microbial Oil Displacement
}

\author{
Chenying Wang \\ Geological Research Institute of the Tenth Oil Production Plant, Daqing Oilfield Co., Ltd., Daqing, Heilongjiang, 163001, China
}

\begin{abstract}
In the context of the rapid development of my country's social economy, the total demand for energy in my country's industrial production continues to increase, of which petroleum energy is an important type of energy required in industrial production. At present, China's petroleum energy mainly depends on imports, so in order to promote the productivity of China's petroleum industry, we must carry out comprehensive innovation of oil displacement technology. Microbial oil displacement is an important technical means, which needs to accurately grasp the factors affecting the oil displacement effect, so as to optimize and innovate the technology. Therefore, this paper will deeply study and analyze the influence of gas distribution on flora structure and oil displacement effect in the process of microbial oil displacement, and put forward some reasonable opinions and measures to further promote the improvement of oil production technology.
\end{abstract}

Keywords: Keywords microbial oil displacement, gas distribution, flora structure, oil displacement effect, influence analysis

\section{Introduction}

Microbial oil displacement technology is a commonly used technology in oil production at present. Compared with other oil displacement technologies, microbial oil displacement has better effect and can effectively improve oil displacement efficiency and quality. The application of microbial oil displacement technology will be influenced by many factors. Among them, gas distribution has a direct influence on the structure of flora. Therefore, it is necessary to clarify the specific way and effect of gas distribution on it, so as to optimize and innovate microbial flooding according to the influence. Therefore, this paper takes the crude oil produced in $\mathrm{H}$ oilfield as a sample through experiments, and makes a comprehensive analysis of its specific influence effect.

\section{Overview of microbial oil displacement technology}

After more than 20 years of development, microbial oil displacement technology has been widely used in the field of oil production. According to the different modes of microbial oil displacement, it can be divided into endogenous microbial oil displacement technology and exogenous microbial oil displacement technology. Because the endogenous microbial flooding can directly utilize the microorganisms in the oil reservoir as the object, the application cost is low, and the workflow of microbial flora fermentation can be saved. At the same time, it can effectively deal with the inadaptability of microbial flora to oil reservoir [1]. Endogenous microbial oil displacement technology can activate aerobic microorganisms in oil fields, making them a component of oil displacement. Therefore, attacking the oxygen needed by the development of aerobic microorganisms is the basis of activating aerobic microorganisms. In related studies, the effects of different gas distribution on the structure of flora were studied. It was found that with the extension of culture time, oxygen would be consumed gradually, and the development of flora was consistent. Some researchers found that gas distribution can directly promote microbial oil displacement in the process of oxygen biological consumption and non biological consumption experiments.

\section{Experimental research}

\subsection{Experimental materials}

The simulated oil field in this experiment is the reservoir condition of $\mathrm{H}$ city oil field. The crude oil sample produced by this oil field is used in physical simulation, which is dehydrated and degassed crude oil. The viscosity of this crude oil sample is $1886 \mathrm{mPa} \cdot \mathrm{s}$ at $50^{\circ} \mathrm{C}$. The water sample in the laboratory is the injection water used in the production of the oilfield, with a salinity of $9980 \mathrm{mg} / \mathrm{L}$. Ions include: $\mathrm{Cl}^{-4} 4568 \mathrm{mg} / \mathrm{L}, \quad \mathrm{HCO}_{3}^{-} 855 \mathrm{mg} / \mathrm{L}, \quad \mathrm{SO}_{4}{ }^{2-}$ 
$106 \mathrm{mg} / \mathrm{L}, \mathrm{Mg}^{2+} 104 \mathrm{mg} / \mathrm{L}, \mathrm{Ca}^{2+} 165 \mathrm{mg} / \mathrm{L} . \mathrm{NA}^{+}+\mathrm{K}^{+}$ $4083 \mathrm{mg} / \mathrm{L}$. According to the oil and gas industry standards, the reservoir conditions of this oil field meet the requirements for microbial growth tolerance. Glucose, $\mathrm{K}_{2} \mathrm{HPO}_{4} 、 \mathrm{H}_{2} \mathrm{SO}_{4} 、 \mathrm{CH}_{3} \mathrm{COOH}$ and analytical reagents are common types in the market. Peptone is produced by a Beijing biological company. The trace element liquid is self-made in the laboratory. The activation system for physical simulation application is: $0.25 \%$ glucose, $0.2 \% \mathrm{~K}_{2} \mathrm{HPO}_{4}, 0.05 \%$ peptone and $0.05 \%$ trace element solution. Quartz sand is produced by Zhonglong Petroleum Corporation. The DNA extraction kit was produced by a bioengineering company in China [2].

The core displacement simulation experiment equipment is produced by a Chinese petroleum instrument company. The gas chromatograph model is GC-14B. The phase contrast microscope model is BX50. The highthroughput sequencer is a general-purpose equipment produced in other countries.

\subsection{Experimental method}

(1) Experimental method design of physical flooding The experimental method design of physical oil displacement includes:(1)Fill the core with quartz sand according to the following configuration, and measure the core permeability. (2) Pumping vacuum saturated formation water and calculating the original water saturation. (3) Make irreducible water from saturated crude oil, and calculate the original water saturation. (4) Place the core at $60^{\circ} \mathrm{C}$ for one week, and displace 3PV by water flooding once, and record the oil production, water production and displacement pressure changes in detail. (5) The microbial nutrient solution $0.3 \mathrm{PV}$ is sequentially mixed with gas according to different volume ratios of $1: 1$, $1: 5$ and 1:10. After the gas distribution is completed, it is injected into the core tube and cultured for 15 days. (6) Secondary water flooding $3 \mathrm{PV}$, recording the changes in oil production, water production and displacement pressure during the period, and calculating the oil displacement and water cut.

Table 1 Quartz sand configuration of sand-filled core

\begin{tabular}{ccc}
\hline Mesh & Particle size & Particle fraction \\
\hline $30-40$ & $590 \mu \mathrm{m}-$ & $8.7 \%$ \\
& $420 \mu \mathrm{m}$ & \\
$40-60$ & $420 \mu \mathrm{m}-$ & $12.1 \%$ \\
& $250 \mu \mathrm{m}$ & \\
$60-80$ & $250 \mu \mathrm{m}-$ & $31.2 \%$ \\
& $178 \mu \mathrm{m}$ & \\
$80-100$ & $178 \mu \mathrm{m}-$ & $27.7 \%$ \\
$100-150$ & $150 \mu \mathrm{m}$ & $13.8 \%$ \\
$200-300$ & $75 \mu \mathrm{m}-59 \mu \mathrm{m}$ & $3.2 \%$ \\
\hline
\end{tabular}

The figure below shows the structure of the device used in the core displacement experiment.

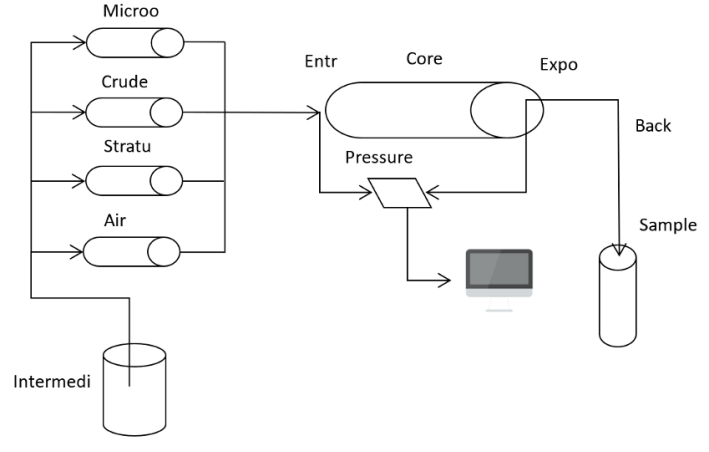

Figure 1 The structure diagram of the device used in the core flooding experiment

\section{(2) Gas distribution}

According to the pore volume of the core, the volume of nutrient solution required under the condition of $0.3 \mathrm{PV}$ is calculated, and the air quantity required under the normal pressure is calculated according to the liquid-gas ratio value designed in the experimental scheme, and the air quantity is calculated according to the setting of different core liquid-gas ratios. The middle container is used for gas distribution, the lower layer is designed as nutrient solution, and the upper layer is designed as air, which is mixed and injected into the core tube, so as to complete the injection test with different gas distribution [3].

(3) Molecular biology measurement of output fluid

In the process of physically simulating core tube displacement, $20 \mathrm{~mL}$ of produced liquid is placed in a centrifugal tube, centrifuged at $4^{\circ} \mathrm{C}$ and $10,000 \mathrm{rpm}$ for 10 minutes, then the bacteria are collected and the supernatant is removed. DNA samples of flora were collected by DNA extraction kit, and then dissolved in water by aseptic method. DNA samples were detected by electrophoresis to ensure sufficient collection, and finally high-throughput sequencing was performed.

(4) Measurement of small molecule acid in produced liquid

In this experiment, the measurement of small molecules in the output liquid adopts the appearance method, and the tested samples and standard samples are analyzed one by one by gas chromatography analysis method to obtain the concentration of small molecules acid in the output liquid. Specifically, it includes: (1) standard sample configuration. The acetic acid standard sample and distilled water were mixed to obtain small molecular acid solutions with different concentrations. (2) Pretreatment of produced liquid samples. Use $10 \mathrm{~mL}$ produced liquid sample, observe the oil-water separation after standing, collect the supernatant after complete separation, and use $0.45 \mu \mathrm{m}$ microporous filter membrane, add sulfuric acid in the ratio of 1:1 to the filtrate, and then refrigerate for one day. (3) Chromatographic analysis. Chromatographic analysis was carried out on standard samples and tested samples to obtain the concentration of small molecular acids in the produced solution. 


\section{Results and discussion}

\subsection{Influence of different gas distribution on displacement effect of physical simulation}

The results of physical simulation oil displacement with different gas distribution are shown in the following table.

Table 2 The results of physical simulation flooding with different gas distribution

\begin{tabular}{|c|c|c|c|c|c|c|c|}
\hline $\begin{array}{l}\text { Co } \\
\text { re }\end{array}$ & $\begin{array}{c}\text { Pore } \\
\text { volu } \\
\text { me }\end{array}$ & $\begin{array}{c}\text { Satur } \\
\text { ated } \\
\text { oil }\end{array}$ & 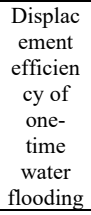 & $\begin{array}{c}\text { Liquid } \\
\text {-gas } \\
\text { ratio }\end{array}$ & $\begin{array}{l}\text { Displac } \\
\text { ement } \\
\text { efficien } \\
\text { cy of } \\
\text { seconda } \\
\text { ry water } \\
\text { flooding }\end{array}$ & $\begin{array}{c}\text { Averag } \\
\text { e } \\
\text { displace } \\
\text { ment } \\
\text { efficien } \\
\text { cy }\end{array}$ & $\begin{array}{c}\text { Displac } \\
\text { ement } \\
\text { improve } \\
\text { s } \\
\text { efficien } \\
\text { cy }\end{array}$ \\
\hline 1 & $\begin{array}{l}244 \\
\mathrm{~mL}\end{array}$ & $\begin{array}{c}209 \mathrm{~m} \\
\mathrm{~L}\end{array}$ & $49.52 \%$ & $\begin{array}{c}\text { No gas } \\
\text { distrib } \\
\text { ution }\end{array}$ & $6.05 \%$ & \multirow{2}{*}{$6.02 \%$} & \multirow{2}{*}{-} \\
\hline 2 & $\begin{array}{l}251 \\
\mathrm{~mL}\end{array}$ & $\begin{array}{c}216 \mathrm{~m} \\
\mathrm{~L}\end{array}$ & $48.05 \%$ & $\begin{array}{c}\text { No gas } \\
\text { distrib } \\
\text { ution }\end{array}$ & $5.99 \%$ & & \\
\hline 3 & $\begin{array}{l}230 \\
\mathrm{~mL}\end{array}$ & $\begin{array}{c}215 \mathrm{~m} \\
\mathrm{~L}\end{array}$ & $47.51 \%$ & $1: 1$ & $10.72 \%$ & \multirow{2}{*}{$10.58 \%$} & \multirow{2}{*}{$4.56 \%$} \\
\hline 4 & $\begin{array}{l}230 \\
\mathrm{~mL}\end{array}$ & $\begin{array}{c}216 \mathrm{~m} \\
\mathrm{~L}\end{array}$ & $46.03 \%$ & 1:1 & $10.44 \%$ & & \\
\hline 5 & $\begin{array}{l}240 \\
\mathrm{~mL}\end{array}$ & $\begin{array}{c}225 \mathrm{~m} \\
\mathrm{~L}\end{array}$ & $47.51 \%$ & $1: 5$ & $14.89 \%$ & \multirow{2}{*}{14.79} & \multirow{2}{*}{$8.77 \%$} \\
\hline 6 & $\begin{array}{l}231 \\
\mathrm{~mL}\end{array}$ & $\begin{array}{c}215 \mathrm{~m} \\
\mathrm{~L}\end{array}$ & $50.50 \%$ & $1: 5$ & $14.68 \%$ & & \\
\hline 7 & $\begin{array}{l}229 \\
\mathrm{~mL}\end{array}$ & $\begin{array}{c}210 \mathrm{~m} \\
\mathrm{~L}\end{array}$ & $49.04 \%$ & $1: 10$ & $14.36 \%$ & \multirow{2}{*}{$16.66 \%$} & \multirow{2}{*}{8.54} \\
\hline 8 & $\begin{array}{l}238 \\
\mathrm{~mL}\end{array}$ & $\begin{array}{c}225 \mathrm{~m} \\
\mathrm{~L} \\
\end{array}$ & $50.07 \%$ & $1: 10$ & $14.95 \%$ & & \\
\hline
\end{tabular}

From the data in the above table, it can be seen that when different gas distribution rates are used, the displacement effect for the acquisition effect is directly affected. Under the condition of increasing gas distribution, the microbial displacement effect is gradually enhanced. It shows that increasing the gas distribution can activate the aerobic microorganisms in the core and promote the growth of aerobic microorganisms. Under the condition of increasing gas distribution, the increasing rate of displacement efficiency keeps decreasing. When the gas-liquid ratio is $1: 5$, the displacement efficiency is the highest, reaching $8.77 \%$. Under four different conditions of unbalanced gas and gas-liquid ratio of $1: 1,1: 5$ and $1: 10$, the water content decreased by $1.53 \%, 2.66 \%, 7.31 \%$ and $6.98 \%$. With the increase of gas distribution, the maximum reduction range of water content gradually increases, and the maximum reduction range of water content is at the condition of liquid gas ratio of 1:5. It shows that reasonable gas distribution can activate useful microorganisms, facultative anaerobic and anaerobic microorganisms to act in crude oil and improve displacement efficiency [4].

\subsection{Changes of produced fluid flora in the process of physical simulation displacement}

\section{Bacterial number change}

The changes in the number of bacteria in the produced fluid with different gas distribution rates during the displacement period are shown in the figure below.

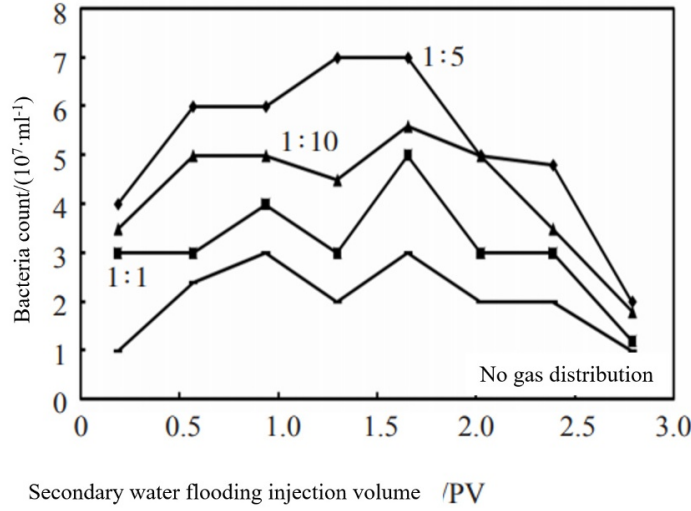

Figure 2 Changes in bacterial counts of produced fluids with different gas distribution rates during displacement

According to the above figure, it can be seen that the number of bacteria in the core produced fluid exceeds $10,000,000 / \mathrm{mL}$, indicating that the microorganisms in the core are fully activated. The number of bacteria in the output liquid is different in different liquid-gas ratios, and the number of bacteria in the output liquid will increase with the increase of gas distribution, which is the same as the above test results. When the liquid-gas ratio was 1:10, aerobic microorganisms were fully activated, but the activated number of facultative anaerobic and anaerobic bacteria was less than that of aerobic bacteria, so the overall number of bacteria decreased. In the process of core displacement, the number of bacteria increased first and then decreased, indicating that microorganisms gradually moved forward in the rock core. Under the condition of displacement 1-2PV, the number of bacteria is the highest, and the increase of the number of bacteria indicates that microorganisms are fully activated and grow, so as to improve the displacement effect [5].

(1) Changes in produced fluid flora

Under different liquid-gas ratios, there are some differences between microbial community structures. Different gas distribution can activate different types of microorganisms, in which the dominant flora accounts for more than $66 \%$ of the total. The following table shows four kinds of functional bacteria after microbial activation under different gas-liquid ratios.

Table 3 Proportion of four different types of functional bacteria

\begin{tabular}{ccccc}
\hline \multirow{5}{*}{ Bacteria } & \multicolumn{5}{c}{ The proportion of different gas distribution } \\
& $\begin{array}{c}\text { No gas } \\
\text { distribution }\end{array}$ & $1: 1$ & $1: 5$ & $1: \quad 1$ \\
\hline $\begin{array}{c}\text { Bacillus } \\
\text { Ferribacillus }\end{array}$ & $16.99 \%$ & $44.15 \%$ & $50.10 \%$ & $28.31 \%$ \\
$\begin{array}{c}\text { ferrooxidans } \\
\text { Pseudomonad }\end{array}$ & $47.13 \%$ & $1.25 \%$ & $8.59 \%$ & $0.49 \%$ \\
$\begin{array}{c}\text { Symbiotic } \\
\text { corpuscle }\end{array}$ & $5.27 \%$ & $3.65 \%$ & $3.02 \%$ & $38.80 \%$ \\
\hline
\end{tabular}

According to the above table, the proportion of Bacillus in different gas distribution conditions is kept high, and it is the main bacteria genus of microbial oil displacement. After activation, the proportion of Bacillus under different liquid-gas ratios is the highest when the liquid-gas ratio is $1: 5$, reaching $51.10 \%$, which is 
consistent with the highest oil displacement effect. Ironremoving bacteria have the characteristics of nitrate reduction and degradation of crude oil, with the highest proportion of $47.13 \%$. With the increase of gas distribution, the proportion is decreasing continuously, which corresponds to its growth and metabolism law. Pseudomonas is a facultative aerobic microorganism, which can metabolize and produce emulsifier to degrade crude oil. Under different gas distribution conditions, the proportion exceeds $10 \%$, and the proportion gradually increases with the increasing gas distribution, which indicates that Pseudomonas has a good response to oxygen. Symbiosis bacteria are microorganisms that coexist with other bacteria and play an important role in maintaining the diversity of biota. Under the condition of liquid-gas ratio of 1: 10, the proportion is significantly higher, indicating that oxygen has a good activation and promotion effect on symbiotic corpuscles.

Under different gas-liquid-gas ratios, the Shannon diversity distribution indices of microorganisms are 1.95, $2.19,2.22$ and 1.66, respectively. With the gradual increase of gas distribution, Shannon diversity index will increase continuously, indicating that oxygen can activate microbial flora. The Shannon diversity index decreased when the gas distribution reached 1:10, which indicated that the aerobic to facultative aerobic microorganisms in the flora increased continuously with the increase of oxygen, but the diversity decreased. From the point of view of finishing trend, the diversity of microbial flora is the best under the condition of liquid-gas ratio of $1: 5$, and in this case, the functional microorganisms are mainly Bacillus and Pseudomonas which produce surface or week and emulsifier, and the displacement effect is the best. According to the results of molecular biology analysis, the conclusion that gas distribution can influence the oil displacement effect is verified [6].

\section{Conclusions}

In the process of microbial oil displacement, injecting different gas distribution can have a direct impact on flora structure and oil displacement effect. The activation of different types of functional microorganisms is different after different air distribution is injected. Among them, the dominant functional bacteria account for more than $66 \%$, and the functional microorganisms are mainly Bacillus and Pseudomonas which produce surfactants and emulsifiers. The concentration of small molecule acids increased after gas distribution, which indicated that oxygen could promote the activation of aerobic microorganisms. Under the condition of liquid-gas ratio of $1: 5$, the concentration of small molecular acids was significantly increased, and the metabolic activity of microorganisms was improved. With the increasing gas distribution, the microbial displacement efficiency gradually increases and tends to be stable. Under the condition of liquid-gas ratio of 1:5, the displacement effect is the best, reaching $8.77 \%$. Therefore, when adopting microbial oil displacement technology, it is necessary to adjust the gas distribution, and adjust the gas distribution to the best state according to the actual production situation of the oil field, so as to improve the oil displacement effect, promote the level of oil displacement technology and increase the oil field output.

To sum up, this paper studies the influence of different gas distribution on the characteristics of flora and oil displacement effect in the process of microbial oil displacement through experiments. The results show that different gas distribution will have a direct impact on the characteristics of flora and oil displacement effect, and a reliable conclusion is obtained. I hope it can be used as a reference and help for the development of China's petrochemical industry. Based on this conclusion, the specific application of microbial oil displacement technology can be adjusted, so as to promote the improvement of oil displacement technology level and continuously improve the productivity of petrochemical industry. At the same time, innovate other oil displacement technologies to promote the development and construction of petrochemical industry.

\section{References}

1. Jing, Shu Qinglin, Sun Gangzheng, et al. The succession of endogenous microorganisms in reservoirs and their influence on oil displacement[J]. Journal of China University of Petroleum: Edition of Natural Science, 2019, 43(001): 7-7.

2. Liu Tao, Wang Lushan, Hu Jing, et al. The influence of gas allocation on the microbial community structure and oil displacement effect in the process of microbial flooding[J]. Oilfield Chemistry, 2019, 36(001):5-5.

3. Sun Gangzheng, Qian Qin, Hu Jing, et al. Research on endogenous microbial flooding laws of Zhan 3 reservoir under different types of activators[J]. Journal of Xi'an Shiyou University: Natural Science Edition, 2019,000(002) :8-8.

4. Yang Xiuqing, Liang Qi, Han Zuoying. The effect of ethanol on the structure of coal geomicrobial flora and gas production pathways in the process of biogas formation[J]. Journal of Shanxi University: Natural Science Edition, 2019, 42(4):10- 10.

5. Song Shemin. Microbial field enhanced oil recovery technology for target dominant bacteria in oil reservoir[J]. Petroleum Drilling \& Production Technology, 2019, 41(002):6-6.

6. Hou Zhaowei, Li Wei, Le Jianjun, et al. Research and application of microbial oil recovery technology in Daqing Oilfield[J]. Petroleum Geology and Recovery Efficiency, 2021, 28(002): 8-8. 